\title{
STUDI ETNOGRAFI ORANG BANJAR DI KABUPATEN INDRAGIRI HILIR PROPINSI RIAU
}

\author{
Edi Susrianto Indra Putra \\ Universitas Islam Indragiri, Tembilahan \\ Email: Ediunisi1971@gmail.com
}

\begin{abstract}
Humans as social beings must be able to interact in the midst of society. Social interaction is the most important requirement for various social activities. Interaction is a reflection of dynamic social relationships involving individual relationships, between groups, and between individuals with groups. As a pluralistic nation, Indonesia is a linkage of various elements in the form of communities and associations that have the same goal, which is to achieve a level of prosperity in accordance with human dignity and dignity. To achieve these goals, it is felt the need for a cultural foundation in the form of the potential for social capital in the attitudes and behaviors of various ethnic groups so that the objectives to be achieved can be realized. The approach taken in this study uses ethnographic studies. The use of ethnographic studies aims to determine the diversity (diversity) and specificity (particularity) of the object under study. So the final result to be obtained is to explain some aspects that are being studied, both about the ethnic origin, cultural and socio-economic forms. The Banjar people in this research concept are Banjar ethnic people or descendants from South Kalimantan who now live in Indragiri Hilir Regency.
\end{abstract}

Keyword: Ethnographic Studies, Banjar People and Indragiri Hilir.

\begin{abstract}
Abstrak
Manusia sebagai makhluk sosial, harus mampu melakukan interaksi di tengah-tengah masyarakat. Interaksi sosial merupakan syarat yang paling penting agar terjadinya berbagai aktivitas sosial. Interaksi merupakan cerminan hubungan sosial yang dinamis menyangkut hubungan orang perorang, antar kelompok, maupun antar orang perorang dengan kelompok. Sebagai bangsa yang plural, Indonesia merupakan pertalian dari berbagai elemen baik yang berbentuk komunitas maupun asosiasi yang memiliki tujuan yang sama, yaitu mencapai tingkat kesejahteraan yang sesuai dengan harkat dan martabat kemanusiaan. Untuk mencapai tujuan tersebut, dirasakan perlunya adanya landasan kultural berupa potensi modal sosial dalam sikap dan perilaku berbagai etnik agar tujuan yang ingin dicapai dapat terwujud. Pendekatan yang dilakukan dalam penelitian ini menggunakan studi Etnografi. Penggunakan studi Etnografi bertujuan untuk mengetahui keragaman (diversity) dan kekhususan (particularity) objek yang diteliti. Sehingga hasil akhir yang ingin diperoleh adalah untuk menjelaskan beberapa aspek yang sedang diteliti, baik tentang asal usul etnis, bentuk kebudayaan maupun sosial ekonomi. Orang Banjar dalam konsep penelitian ini adalah orang atau keturunan etnis Banjar yang berasal dari Kalimantan Selatan yang sekarang bermukim di Kabupaten Indragiri Hilir.
\end{abstract}

Kata Kunci: Studi Etnografi, Orang Banjar dan Indragiri Hilir.

\section{PENDAhUluAN}

Indragiri Hilir pada masa kolonial Belanda termasuk salah satu wilayah Afdeeling Indragiri, Keresidenan Riouw. Afdeling ini memiliki luas 22.090,50 KM yang terdiri atas tiga Onderafdeeling, yakni Taluk Kuantan, Indragiri Hulu, dan Indragiri Hilir. Ketika Indonesia telah merdeka terutama sekali saat Riau menjadi sebuah propinsi pada tahun 1958, Indragiri Hilir adalah salah satu kabupaten yang terdapat di wilayah itu.
Wilayah Indragiri Hilir merupakan hamparan daratan rendah, yang berawa-rawa, tanahnya bergambut, sementara itu delta sungai Indragiri bermuara ke pantai timur berhadapan langsung dengan muka Selat Berhala. Daerah tersebut sebetulnya memiliki beberapa sungai. Namun sungai yang terpenting dalam ensiklopedi Hindia Belanda adalah sungai Indragiri atau disebut juga dengan sungai Batang Kuantan. Airnya mengalir ke Afdeeling Indragiri. Fungsi sungai 
tersebut bagi masyarakat Indragiri Hilir berperan sangat penting untuk berjalannya roda perekonomian daerah, misalnya untuk pengangkutan karet, kelapa, dan hasil bumi lainnya. Sebelum pembukaan jalan Taluk Kuantan - Pekanbaru pada tahun 1929, sungai merupakan satu-satunya akses penghubung dengan Pantai Barat Sumatera.

Terkait dengan hal tersebut, secara tidak langsung menempatkan daerah Indragiri Hilir pada posisi yang strategis dalam konteks jalur perdagangan antar daerah pesisir. Tidak mengherankan jika pada saat itu hubungan lalu lintas melalui sungai-sungai dan laut menggunakan perahu dan kapal layar sebagai sarana transportasi yang paling efektif, karena bisa ditempuh dengan mudah. Dalam konteks Onderafdeeling Indragiri Hilir pada masa pemerintahan kolonial Belanda dibagi atas tujuh distrik, yaitu: Tembilahan, Tempuling, Sungai Luar, Enok Dalam, Mandah, Gaung, dan Retih.

Penduduk Indragiri Hilir pada awal abad ke-20, berjumlah kira-kira 100.000-an jiwa. Jumlah itu berasal dari berbagai suku bangsa yang ada di sana. Jumlah terbesar di antara suku bangsa itu berasal dari penduduk pribumi yang terdiri atas orang Melayu dan orang Laut. Jumlah mereka sekitar 65.914 jiwa, selebihnya adalah pendatang. Dalam konteks orang Melayu yang bermukim di Indragiri Hilir kiranya perlu juga untuk dikemukakan dalam penelitian ini. Sebab tidak semua orang Melayu yang menetap di Onderafdeeling itu adalah penduduk asli, melainkan sebagian di antara mereka adalah kaum pendatang yang berasal dari Indragiri Hulu, terutama mereka yang tinggal di Anak Serka di distrik Gaung (Muthalib; 2008).

Orang Banjar yang bermukim di Kabupaten Indragiri Hilir merupakan keturunan para migran Banjar terdahulu yang berasal dari Kalimantan Selatan. Awal kedatangan mereka ke daerah Indragiri Hilir sampai saat ini masih menjadi perdebatan di kalangan para peneliti. Dari berbagai sumber menyebutkan bahwa beberapa suku yang merantau ke daerah Indragiri Hilir di akhir abad ke-19 itu adalah orang Banjar, Bugis, Melayu Palembang, Cina, bangsa Eropa, dan Timur Asing lainnya. Dalam buku "Sejarah Riau" disebutkan bahwa pada masa pemerintahan Sultan Isya Muddayat Syah tahun 1895 sudah ditemukan pemukiman orang Banjar di wilayah ini. Kedatangan para perantau Banjar ini disebabkan karena dibukanya perkebunan besar di wilayah Kesultanan Indragiri pada waktu itu. Mereka tinggal di sepanjang aliran sungai Indragiri mulai dari Kuala Cenako sampai Perigi Raja. (Lutfi, 1977; Muthalib; 2008).
Orang Banjar mulai masuk ke Indragiri Hilir sejak akhir abad ke-19 (Naim, 1984:45). Namun ada juga sebagian sumber yang tidak sependapat dengan pendapat di atas, yang mengatakan bahwa orang Banjar sudah mulai masuk ke Indragiri kira-kira tahun 1910-an. Secara turun temurun, orang Banjar diperkirakan sudah ada dan bermukim di Sapat sebelum tahun 1910-an. Sebab realitas di lapangan menunjukkan bahwa tahun 1910-an pohon kelapa ketika itu telah tumbuh setinggi anjungan rumah kira-kira empat meter. Kelapa yang tumbuh setinggi empat meter itu biasanya telah berumur 7 9 tahun sejak kelapa tersebut ditanam. Kenyataan inilah salah satu bukti bahwa kehadiran orang Banjar di Indragiri telah ada jauh sebelumnya.

Menurut catatan Van Vollen hobven seperti yang dikutip Juwono (2005:355) menugungkapkan bahwa orang Banjar telah mulai masuk dan bermukim di Indragiri Hilir pada tahun 1900 sekitar 1000 jiwa. Lima belas tahun kemudian (1915) jumlah mereka meningkat drastis, yakni 18.798 jiwa. Pada akhir Perang Dunia I atau dekade kedua abad ke-20 jumlah mereka diperkirakan 20 ribu jiwa. Kesulitan untuk mengetahui sejak kapan orang Banjar mulai datang ke Indragiri Hilir, disebabkan karena luasnya daerah Riau, yang terdiri dari belahan kepulauan yang terletak di selat Malaka sampai ke laut Cina Selatan dan belahan daratan di pulau Sumatera yang berbatasan dengan Sumatera Utara, Sumatera Barat dan Jambi, benarbenar suatu daerah yang cukup luas. Oleh sebab itu jika perantau Banjar masuk ke daerah ini, akan susah dikenal atau dicatat.

Orang Banjar di awal kedatangannya di Indragiri Hilir bermukim di wilayah Distrik Retih, kemudian pindah ke Distrik Penyimahan, lalu dari sini mereka menyebar ke seluruh Onderafdeeling indragiri Hilir. Tetapi yang lebih dominan mereka tinggal di sepanjang aliran sungai Indragiri, mulai dari Kuala Cenaku sampai Perigi Raja. Kenyatan ini menggambarkan bahwa orang Banjar dalam kehidupan sehari-hari lebih akrab dengan dunia pertanian. Karena di distrikdistrik yang dikemukakan itu merupakan daerah-daerah pertanian yang subur, baik untuk perkebunan kelapa maupun persawahan. Setelah beberapa tahun kehadiran mereka di Indragiri Hilir yang diiringi dengan kerja keras, sehingga membuahkan hasil yang menggembirakan. Di Indragiri Hilir, petani Banjar merintis daerah rawa pasang surut untuk menanam padi, kelapa dan berbagai tanaman lainnya. 


\section{Metodologi Penelitian}

Sesuai dengan pokok permasalahan yang telah dirumuskan, penelitian ini menggunakan pendekatan kualitatif. Alasan pemilihan metode kualitatif dikarenakan subjek penelitiannya adalah gejala-gejala sosial (social life) yang dinamis. Dalam hal ini subject matter penelitian adalah orang Banjar yang ada di Kabupaten Indragiri Hilir. Pendekatan yang dilakukan dalam penelitian ini menggunakan jenis Studi Etnografi. Melalui pendekatan Studi Etnografi, diharapkan dapat mengungkapkan tentang Kajian Etnisitas orang Banjar, bentuk interaksi sosial dan budaya di Kabupaten Indragiri Hilir (Spradley, 1972; Creswell, 1994).

\section{Orang Banjar dalam Pengertian Etnisitas}

Secara etimologi kata etnik (ethnic) berasal dari bahasa Yunani, yaitu "etnichos", yang secara harfiah digunakan untuk menerangkan keberadaan sekelompok orang di tempat tertentu. Sedangkan Barth berpendapat bahwa etnik adalah himpunan manusia karena kesamaan ras, agama, asalusul bangsa taupun kombinasi dari kategor yang terikat pada sistem nilai budaya. Anggota kelompok suatu etnik memiliki kesamaan dalam hal sejarah, bahasa, sistem nilai, serta adat istiadat dan tradisi. Istilah "etnik" sendiri merujuk pada pengertian kelompok orang-orang, sedangkan "etnis" merujuk pada orang-orang dalam kelompok. Dalam penelitian ini kedua istilah tersebut akan digunakan secara bergantian, tergantung dengan konteks yang sedang dibicarakan (Liliweri, 2001; Barth, 1969).

Istilah Etnis menunjukkan suatu kelompok masyarakat yang membedakan antara satu kelompok dengan kelompok lain. Etnis ditandai dengan kriteria bahasa, organisasi politik, teritorial tempat tinggal. Di antara unsur-unsur yang membedakan tersebut tidak persis sama, hal ini sangat tergantung pada para ahli yang memberikan batasan tentang etnis tersebut. Misalnya secara kultural dua kelompok kebudayaan yang sama, tetapi secara ras mungkin sangat berbeda. Adanya etnisitas tentunya telah mempunyai saling keterkaitan antara satu kelompok dengan kelompok yang berlainan saling berhubungan. Apabila ada perbedaan budaya secara reguler sekaligus menimbulkan suatu perbedaan dalam interaksi di antara anggota kelompok, maka hubungan sosial tersebut akan memiliki suatu unsur etnis.
Etnisitas menunjukkan pada aspek untung-rugi atau positif-negatif dalam berinteraksi, dan juga menunjukkan pada aspek makna penciptaan identitas. Dengan kata lain, etnisitas memiliki unsur politik, organisasi, dan aspek simbolis. Menurut Parsons (Sihaloho, 2006:418), identitas etnik (ethnic identity) adalah "the pattern maintance code system of individual personality", yakni sistem pola pemeliharaan kepribadian individu. Artinya terdapat kriteria tertentu yang menandai dan menetukan bahwa sesuatu hal yang menjadi identitasnya.

Dari paparan di atas sangat jelas, bahwa etnisitas merupakan suatu kelompok masyarakat yang hidup bersama masyarakat lain, tetapi mereka berbeda secara budaya, bahasa, dan sistem organisasi. Demikian halnya etnisitas merupakan ciri khas dari suatu masyarakat yang hidup dan berinteraksi dengan etnis lain. Etnisitas pun merujuk pada aspek positif-negatif dalam berintegrasi dan juga menunjukkan pada aspek makna dalam penciptaan identitas. Dengan demikian, etnisitas memiliki nuansa politik, organisasi, dan simbolis.

\section{Sejarah Asal-usul Orang Banjar}

Sebelum berbicara lebih jauh tentang asal usul pembentukan orang Banjar, terlebih dahulu penulis akan diuraikan tentang konsep orang Banjar dan asal usul mereka secara umum. Dari berbagai literatur yang ditemui, ada banyak versi tentang asal usul pembentukan orang Banjar. Menurut catatan sejarah, pada masa dahulu daerah Kalimantan dihuni oleh dua kelompok besar dari daratan Asia yang ribuan tahun lalu bermigrasi ke Kalimantan, yaitu kelompok Proto-Melayu dan Deutro-Melayu. Kedatang dua kelompok besar ini ke Kalimantan mempunyai jalur dan waktu yang berbedabeda. Penduduk yang datang ke Kalimantan Tengah dan Kalimantan Selatan, untuk beberapa waktu kemungkinan besar singgah terlebih dahulu di pulau Jawa dan Sumatera. Sedangkan mereka yang kemudian menghuni Kalimantan Timur dan Barat, kemungkinan tidak singgah di pulau Jawa. Kelompok yang singgah di Kalimantan Tengah yang disebut dengan Proto-Melayu, dikenal dengan bangsa Maayan, sedangkan yang singgah di Kalimantan Selatan disebut dengan DeutroMelayu, kelompok inilah yang kita kenal dengan orang Banjar sekarang (Coomans, 1987:2). Salim, 2001:5).

Sebutan "Banjar" pada mulanya dimaksudkan untuk memisahkan antara orang Jawa dan orang Melayu. Pada masa 
pemerintahan Pangeran Samudra atau setelah memeluk agama Islam dikenal dengan nama Sultan Suriansyah, memerintahkan untuk membangun perkampungan kelompok Jawa di hilir tepi sungai Martapura, sedangkan kelompok Melayu di tepi hulunya. Kampung-kampung inilah yang semula di sebut Banjar. Sehingga orang Banjar adalah sebutan untuk mereka yang tinggal di kampung-kampung di wilayah Kesultanan Banjar (Basri, 1988:43). Namun konsep ini kemudian berubah. Kata "Banjar" kemudian digunakan sebagai konsep untuk menyebut orang-orang yang ada di Kalimantan yang bergama Islam dan berbahasa Banjar (Daud, 1997:7).

Menurut Daud (1997:25) suku Banjar adalah bentukan dari suku Dayak Maayan, Lawangan, Bukit Meratus dan Dayak Ngaju. Melalui proses pembauran selama berabadabad, suku-suku ini berubah dengan cara meninggalkan bahasa mereka dan menggunakan bahasa Melayu dan kata-kata Jawa serta masuk Islam. Sedangkan mereka yang tidak memeluk agama Islam dan tidak berbahasa Banjar tetap menyebut dirinya sebagai orang Dayak. Di sini tampak jelas bahwa Banjar sebenarnya merupakan pecahan dari kelompok-kelompok Dayak yang besar. Karena itulah orang Dayak yang masuk ke dalam wilayah ini disebut "jadi orang Banjar". Faktor pemisahan ini terutama adalah karena perbedaan pandangan spiritual dan keagamaan. Di sini konsep "Banjar" lebih merujuk pada istilah sosio-religius. Banjar menjadi identitas agama dan sekaligus suku. Identitas baru ini membawa orang Dayak dan orang Banjar terlibat dalam kontestasi di berbagai bidang kehidupan.

Dalam sebuah cerita Dayak Meratus, dikisahkan bahwa orang Banjar dan orang Dayak pada awalnya berasal dari dua bersaudara, yaitu Sandayuhan dan adiknya, Bambang Basiwa. Keduanya memiliki watak yang berlawanan, sehingga membuat keduanya tidak mendapat kecocokan dan akhirnya berpisah dan jalan masing-masing. Sandayuhan yang memiliki kebiasaan dan watak yang buruk dalam cerita itu kemudian menurunkan orang-orang Dayak Meratus, dan Bambang Basiwara yang memiliki sifat baik kemudian menjadi nenek moyang orang Banjar (Tsing, 1998:56-58). Menurut Radam (2001:106) orang Dayak (Bukit) memang serumpun dengan orang Banjar (Hulu). Oleh karena adanya benturan kepentingan dengan masyarakat lainnya, kelompok-kelompok tertentu dalam rumpun tersebut mulai terdesak ke arah udik dan ke daerah bergunung-gunung, mempertahankan kebiasaan lama dan mengembangkan kebudayaan baru.

Orang Banjar, seperti yang dikemukakan Abdussami (1996:113) memang merupakan komunitas etnik atau kumpulan asli penduduk Kalimantan Selatan yang termasuk dalam kelompok Melayu Muda (terdiri dari etnik Melayu, ditambah dengan unsur Bukit, Nagaju dan Maayan) yang umumnya tinggal di sekitar pantai dan memeluk agama Islam. Kendati Banjar sebagian masuk dalam budaya Melayu, tetapi unsur kebudayaan Jawa sangat kuat, baik dalam dunia kraton, bahasa maupun adat istiadat. Sedangkan Najib $(1996 ; 130)$ berpendapat bahwa, bahwa budaya Jawa tidak tidak berpengaruh begitu kuat dalam dan mengakar dalam budaya Banjar, tetapi hanya lapisan tipis tanpa makna yang signifikan. Unsur budaya Melayu tetap dominan dalam budaya Banjar, karena sudah lama menjadi inti dari terbentuknya masyarakat Banjar. Daud (1997:13) berpendapat bahwa inti masyarakat Banjar adalah orang Banjar Pahuluan, yaitu mereka yang bertempat tinggal di lembah sungaisungai yang kecuali sungai Martapura. Mereka pada mulanya berada di hilir Sungai Barito dengan pekerjaan utama bertani, menangkap ikan dan mengambil hasil hutan. Kemudian setelah masuknya para pendatang dan terjadi percampuran di antara mereka dengan orang Melayu, Jawa, Madura, Arab dan India, mereka mulai mengalihkan usaha pertanian ke perdagangan, perikanan dan pertukangan. Usaha ini berkembang di sepanjang aliran sungai Barito dan anak sungainya.

Orang Banjar Pahuluan dan orang Banjar Batang Bayu pada awalnya lebih dikenal dengan mata pencaharian pertanian. Namun kemudian mereka mengembangkan usaha lain, yaitu usaha kerajinan. Dengan sendirinya diperlukan usaha untuk memasarkan produk berbagai usaha kerajinan tersebut. Diantara mereka ada yang memilih usaha memasarkan hasil kerajinan ini dengan cara berdagang dengan menggunakan perahu dari kampung ke kampung. Sebagain dari mereka kemudian memutuskan untuk menetap dan tinggal di Banjarmasin yang merupakan tempat berdirinya kesultanan Banjar. Sejalan dengan terbentuknya Kesultanan Banjar, banyak penduduk yang berpindah ke daerah sekitar keraton baru ini. Sebagain mereka adalah penduduk Negara Daha yang diajak untuk pindah ke sana. Mereka yang berdiam di sekitar kerajaan inilah yang kemudian menamakan dirinya sebagai orang Banjar. Pada perkembangan berikutnya, orang Banjar ini kemudian menyebar keberbagai daerah, seperti ke Sumatera dan 
Semenanjung Malaysia (Naim,1984:42; Mahdini, 2003:9).

Orang Banjar yang ada di Kabupaten Indragiri Hilir terdiri dari beberapa jenis anak suku, yang diberi nama sesuai dengan nama daerah asal mereka di Kalimanatan Selatan. Jenis anak suku tersebut antara lain; Banjar Umuntai, Banjar Negara, Banjar Kalua, Banjarmasin, Banjar Barabai, Banjar Martapura, Banjar Alabio, Banjar Rantau dan Banjar Kandangan. Dari sekian sekian banyak jenis anak suku Banjar yang terdapat di Indragiri Hilir, yang paling dominan adalah Banjar Amuntai dan Banjar Kandangan. Adanya beberapa anak suku Banjar di Indragiri Hilir, menimbulkan pula adanya varian-varian dalam bahasa mereka, sehingga dapat membedakan antara anak suku tersebut dari bahasanya sehari-hari. Perlu diketahui bahwa bahasa Banjar yang terdapat di Kabupaten Indragiri Hilir telah mengalami campuran dari berbagai varian bahasa Banjar dengan sedikit warna bahasa Melayu (Mahdini, 2003:12).

Dari uraian di atas dapat disimpulkan bahwa inti dari pembentukan masyarakat Banjar adalah perpaduan antara kaum imigran Melayu yang melebur dengan berbagai kelompok masyarakat Dayak, khususnya Dayak Bukit, Dayak Maayan, dan Nganju serta berbagai unsur seperti Jawa, Bugis, Arab dan lain-lain. Kesatuan dari berbagai etnis dan latar belakang budaya inilah yang nantinya dikenal dengan sebutan orang Banjar.

\section{Pembahasan Hasil Penelitian}

Kedatangan orang Banjar ke Indragiri Hilir tidak terlepas dari kondisi politik, sosial dan ekonomi yang terjadi di daerah asal mereka Kalimantan Selatan. Ketika daerah Kalimantan Selatan dilanda peperangan dan kesulitan ekonomi, orang Banjar mencari daerah penghidupan baru dengan cara melakukan migrasi. Menurut catatan sejarah, orang Banjar sudah mulai masuk dan bermukim di daerah Indragiri Hilir sejak abad ke-19, pada masa pemerintahan Sultan Isa Mudayat Syah. Keberhasilan orang Banjar di Indragiri Hilir pada awal tahun 1900-an, tidak terlepas dari peranan salah seorang tokoh Banjar yang bernama Syekh Abdurrahman Siddiq. Di samping seorang ulama, beliau juga merupakan tokoh pendidikan yang telah berjasa merobah pola pikir masyarakat Banjar pada masa itu. Salah seorang narasumber dalam penelitian ini menuturkan, Syekh Abdurrahman Siddiq adalah seorang ulama dan tokoh Pendidikan Islam di Indragiri Hilir. Beliau adalah seorang migran Banjar yang datang ke Indragiri Hilir sekitar tahun 1908. Aktivitas dan peranannya di tengahtengah masyarakat Banjar ketika itu sangat berpengaruh sekali. Di samping berperan sebagai ulama dan juru dakwah, beliau juga mendirikan sebuah Madrasah di Kampung Hidayat Sapat, yang lambat laun berkembang menjadi pesantren. Kepindahan Syekh Abdurrahman Siddiq ke Sapat benar-benar telah menghidupkan daerah ini yang sebelumnya hanya dikenal sebagai daerah pedalaman. Tetapi berkat usaha yang dilakukan beliau, daerah ini menjadi dikenal, tidak hanya karena aktifitas dakwahnya, tetapi juga karena aktifitas perekonomiannya (Hasil wawancara dengan Narasumber).

Daerah Sapat merupakan kantong pemukiman terbesar para migran Banjar di Indragiri Hilir pada awal abd ke-20. Di pilihnya Sapat sebagai tempat pemukiman oleh etnis Banjar, karena daerah ini merupakan daerah yang subur yang terletak di muara Sungai Indragiri, sehingga sangat berpotensi untuk dijadikan daerah perkebunan dan pertanian. Di daerah ini para migran Banjar membuka perkebunan kelapa dan membuat parit-parit besar yang disebut dengan parit induk, yang berguna untuk mengalirkan air ke perkebunan mereka. Pembukaan perkebunan kelapa yang dilakukan orang Banjar di daerah ini semakin lama semakin meluas. Lahan-lahan bergambut tersebut juga mereka tanamai dengan padi dan tanaman palawijah lainnya untuk kebutuhan hidup sehari-hari. Lambat laun daerah Sapat, Retih, dan Kateman akhirnya berubah menjadi perkebunan kelapa dan ladang-ladang padi. Pada Iahan kebun yang luas dan bergambut tersebut, para petani Banjar membuat saluran atau disebut juga dengan parit, yang berfungsi di samping sebagai untuk mengalirkan air pasang laut ke perkebunan mereka, juga berperan sebagai sarana untuk mengangkut buah kelapa yang sudah di panen menuju tempat-tempat penampungan.

Daerah Sapat secara geografis berada di muara Kuala Indragiri. Pada masa kolonial Belanda di daerah ini dibangun sebuah pelabuhan, sehingga terjadilah bongkar muat barang dari dan ke berbagai daerah tujuan, seperti ke Singapura dan lain sebagainya. Oleh karena itu pada abad ke-19 sampai akhir abad ke-20 Sapat sangat terkenal. Buktinya ketika Belanda membuat laporan tentang kondisi daerah Indragiri khususnya yang berkaitan dengan masalah kehidupan keagamaan. Dalam dokumen yang dibuat pemerintah kolonial Belanda terdapat kata "Mufti Sapat" yang menjelaskan bagaimana kiprah dan peranan Syekh 
Abdurrahman Siddiq pada masa itu. Artinya Sapat bisa di katakan "ikon" daerah Indragiri Hilir pada masa itu. Produk dari tanaman kelapa ini pada mulanya digunakan untuk kebutuhan konsumsi sendiri, termasuk juga unsur-unsur dari pohonnya yang bisa digunakan untuk kebutuhan pemukiman. Namun setelah banyaknya permintaan, kelapa-kelapa tersebut kemudian mulai dijual. Mengingat tanah didaerah ini sangat cocok bagi pengembangan tanaman ini, penduduk mulai menanamnya secara teratur. Teknik pertanian yang dikembangkan adalah sistem parit, dan ternyata sistem parit ini cukup berhasil sehingga orang Banjar yang ada di Sapat ketika itu berhasil menjadikan daerah ini sebagai kawasan pertanian yang maju. Dalam waktu yang tidak begitu lama, Sapat tumbuh menjadi pusat perkebunan dan penghasil kelapa di Indragiri Hilir. Keberhasilan migran pendahulu ini, mengundang minat orang Banjar yang ada di Kalimantan Selatan untuk datang ke daerah Indragiri Hilir menyusul sanak saudara mereka. Mereka datang membawa keluarga dan kerabat untuk ikut bertani dan membuka perkebunan kelapa di daerah ini.

Perdagangan dan pengolahan buah kelapa pada saat itu masih dilakukan secara tradisional. Para pembelinya terutama adalah orang-orang Cina atau Minangkabau yang datang ke Indragiri Hilir untuk mengambil buah kelapa dari tanaman milik penduduk disepanjang pantai. Mereka adalah agen dari perusahaan besar di Padang, Medan, dan Tanjung Pinang. Mereka mempergunakan kapal-kapal kayu, perahu dan sekoci untuki mengangkut buah kelapa dengan cara menyusuri sungai-sungai sampai ke pedalaman Indragiri Hilir. Kelapa ini masih dijual dalam bentuk buah dan belum dirubah menjadi kopra. Baru setelah dibukanya perkebunan besar di daerah Indragiri Hilir, masyarakat Banjar tidak lagi menjual buah kelapa saja kepada para agen, tetapi sudah diolah menjadi kopra dan harganya pun jauh lebih tinggi dibandingkan buah kelapa.

Melalui wawancara dengan narasumber di lapangan, diperoleh informasi bahwa orang Banjar yang ada dan bermukim di daerah Indragiri Hilir terdiri dari berbagai anak suku sesuai dengan daerah asal mereka. Salah seorang narasumber penelitian ini menuturkan sebagai berikut, Orang Banjar yang ada di Indragiri Hilir terdiri dari beberapa jenis anak suku, sesuai dengan nama daerah asal mereka di Kalimantan Selatan, seperti Banjar Amuntai, Banjar Negara, Banjar Kalua, Banjarmasin, Banjar Barabai, Banjar Martapura, Banjar Alabio, Banjar Rantau dan Banjar Kandangan. Di antara anak suku Banjar, Banjar Amuntai dan Kandangan yang banyak mendiami Indragiri Hilir. Ada beberapa anak suku seperti diatas, menimbulkan pula adanya varian-varian dalam bahasa mereka, sehingga dapat membedakan di antara anak suku tersebut. Perlu dinyatakan bahwa bahasa Banjar yang terdapat di Indragiri Hilir telah mengalami campuran dari berbagai varian bahasa suku Banjar dengan sedikit warna bahasa Melayu.

Sebelum pembukaan jalan raya Taluk Kuantan - Pekanbaru pada tahun 1929, sungai merupakan satu-satunya akses penghubung antara daerah Indragiri dengan Pantai Barat Sumatera. Sehingga secara tidak langsung menempatkan daerah ini pada posisi yang strategis dalam konteks jalur perdagangan antara daerah pesisir. Oleh karena itunya, tidak heran jika pada saat itu hubungan lalu lintas melalui sungai-sungai dan laut menggunakan perahu kapal layar sebagai sarana transportasi yang paling efektif, karena bisa ditempuh dengan mudah. $\mathrm{Hal}$ ini tentu sangat berpengaruh terhadap dinamika pergerakan mobilitas penduduk dari berbagai daerah. Lancarnya arus transportasi, membawa pengaruh yang sangat besar terhadap mobilitas dan perdagangan di daerah ini. Perdagangan mengalami kemajuan pesat berkat adanya pembukaan pelabuhan di Riau sebagai pelabuhan bebas untuk ekspor-import. Indragiri sebagai daerah penopang (hinterland) yang terletak di jalur perdagangan, memiliki kepentingan besar dengan proses ini sejak tahun 1828. Hal ini sangat berpengaruh pada arus perniagaan dan transportasi dari pedalaman Indragiri menuju pantai, khususnya sejak dibukanya hubungan langsung dengan Singapura sebagai pelabuhan transito internasional. Jalan-jalan tradisional yang ada diperlebar dan diperbaiki, sehingga memudahkan sarana pengangkutan produk setempat menuju ke pusat-pusat perkotaan. Hal ini nampak pada jalan-jalan penghubung antara kota Taluk Kuantan, Rengat, Kuala Cinaku, dan Tembilahan.

Seiring perkembangan zaman, orang Banjar yang ada di Kabupaten Indragiri Hilir sudah banyak melakukan kontak sosial dengan berbagai etnis yang ada di Indragiri Hilir. Terjadinya kontak sosial antara orang Banjar dengan penduduk tempatan dapat dilakukan di berbagai tempat dan kesempatan, seperti di pasar, sekolah, kantor, mesjid, majelis taklim dan lain-lain. Kontak-kontak sosial ini meliputi lapangan ekonomi, sosial budaya, pendidikan dan keagamaan. Salah satu cara yang amat penting dilakukan oleh orang Banjar yang ada 
di Indragiri Hilir adalah melakukan penguasaan bahasa dan dialek-dialek Melayu dalam pergaulan sehari-hari. Inilah yang ikut mendorong terjadinya penerimaan unsurunsur budaya etnis Melayu oleh kalangan orang Banjar, dan sebaliknya orang Melayu dan etnis lainnya juga dapat mengenal serta memahami tradisi orang Banjar dalam kehidupan sehari-hari. Terjadinya apresiasi yang baik terhadap budaya dan perbedaan ini, memberikan peluang kepada orang Banjar untuk hidup berdampingan dengan berbagai budaya yang ada, tidak hanya budaya Melayu, tetapi juga Bugis, Minangkabau, Jawa, Madura, Cina dan lainlain (Hasil wawancara dengan Narasumber).

Dari hasil observasi dan wawancara di lapangan diperoleh keterangan bahwa, pola interaksi yang dilakukan orang Banjar khususnya di kota Tembilahan dilakukan dalam bentuk hubungan transaksi dagang. Hal ini juga sesuai dengan penuturan salah seorang narasumber sebagai berikut; Orang Banjar yang berprofesi sebagai pedagang, selalu melakukan interaksi dan komunikasi dengan etnis lain hampir setiap kali melakukan transaksi dagang, mereka tidak hanya memiliki keintiman dalam berinteraksi, tetapi juga menjalin kerjasama yang erat. Pola komunikasi dan interaksi yang mereka lakukan tidak hanya sebatas pada kepentingan antara penjual dan pembeli berupa adanya tawar menawar sesuatu barang. Kondisi seperti ini berlangsung setiap hari, meskipun tidak menutup kemungkinan adanya interaksi yang mengarah pada pola kerjasama perdagangan atau menjadi hubungan antara pedagang dengan pelanggan.

Keberhasilan pola interaksi sosial seperti ini berlanjut hingga dalam bentuk interaksi sosial kemasyarakatan, misalnya: acara perkawinan, acara kematian, baaruhan, gotong royong, ronda malam, dan sebagainya. Kondisi status sosial dan kondisi ekonomi yang sama antar sesama etnis yang ada di kota Tembilahan diikat oleh sesama jenis pekerjaan yang digeluti mengaburkan adanya kesenjangan sosial yang memicu pada kecemburuan sosial ekonomi diantara berbagai etnis yang ada di Kabupaten Indragiri Hilir. Kesamaan kondisi sosial ekonomi dan kesamaan pekerjaan, khususnya di level menengah ke bawah mengesankan adanya persamaan yang menggambarkan tidak adanya jurang perbedaan antara berbagai etnis yang ada. Keterlibatan dalam kegiatan sosial juga menjadi salah satu aspek terpenting dalam mengukur strategi adaptasi orang Banjar di Kabupaten Indragiri Hilir. Hal ini bisa menjadi tolok ukur untuk melihat sejauh mana integrasi para migran dengan penduduk asli. Ruang interaksi dalam kegiatan sosial ini mendorong terjadinya penguatan kegiatan interaksi, tidak hanya sekedar saling menyapa, tetapi intensitas interaksi turut pula menguatkan dalam bentuk kerjasama di berbagai bidang kehidupan.

\section{Kesimpulan}

Orang Banjar yang ada di Indragiri Hilir adalah salah satu contoh etnis pendatang yang memiliki modal sosial yang baik. Keberhasilan mereka dalam beradaptasi dan berinteraksi dengan berbagai etnis yang ada di Indragiri Hilir, menjadikan orang Banjar sukses dan berhasil di perantauan. Keberhasilan orang Banjar di Indragiri Hilir, tidak hanya ditopang oleh etos kerja baik, tetapi juga karena keberhasilan mereka dalam membangun jaringan sosial dan menjaga hubungan baik antar sesama etnis maupun dengan berbagai etnis yang ada di daerah ini. Pemahaman terhadap ajaran agama yang dianut memberikan kontribusi yang sangat besar dalam proses interaksi sosial. Ajaran-ajaran agama yang mengedepankan rasa kasih sayang antar sesama, menjauhi prasangka negatif terhadap apa yang dilakukan dalam aktivitas ritual keagamaan orang lain akan mendorong dan memudahkan terjadinya interaksi sosial.

Kegiatan keagamaan bagi orang Banjar dianggap sebagai suatu hal yang sangat penting sekali yang tidak dapat diabaikan dengan begitu saja. Kegiatan keagamaan dan ritualitas budaya Islam yang kental dan menonjol yang dilakukan oleh orang Banjar menjadi sarana penghubung yang efektif dalam berkomunikasi dan berinteraksi dengan berbagai etnis yang ada. Tradisi keagamaan yang dianut oleh orang Banjar, menyebabkan mereka mudah diterima dengan baik oleh di berbagai kalangan etnis yang ada. Dalam pandangan etnis lain, etnis Banjar adalah orang yang taat dalam menjalankan ibadah dan ritual agama Islam. Hal ini tentu tidak terlepas dari peranan ulama seperti Syekh Abdurrahman Siddiq, yang telah berjasa dalam memberikan pemahaman terhadap agama Islam. Bahkan beberapa kitab karangan beliau menjadi bahan rujukan tidak hanya oleh kalangan orang Banjar, tetapi umat Islam yang ada di Kabupaten Indragiri Hilir.

\section{DAFTAR PUSTAKA}


[1] Abdussami, H. (1996). "Demokrasi dalam Perspektif Budaya Banjar", dalam Muhammad Najib dkk., Demokrasi dalam Perspektif Budaya Nusantara. Yogyakarta: LKPSM.

[2] Barth, F. (1969). Kelompok-Kelompok Etnik dan Batasannya. Jakarta: Universitas Indonesia Press.

[3] Commans, M. (1987). Manusia Daya; dulu, sekarang dan Masa depan. Jakarta: Gramedia.

[4] Creswell, J. W. (1994). Research Design Qualitative \& Quantitative Approachhes. SAGE Publications International Educational and Professional Publisher Thousand Oaks London New Delhi.

[5] Daud, A. (1997). Islam dan Masyarakat Banjar: Deskripsi dan Analisa Kebudayaan Banjar. Jakarta: Rajawali Press.

[6] Juwono, $\mathrm{H}$ dan Hutagalung, Y. (2006). Tiga Tungku Sejarangan: Sejarah Kesultanan Indragiri sampai Peristiwa 5 Januari 1945. Yogyakarta: Ombak.

[7] Liliweri, A. (2001). Gatra-gatra Komunikasi Antar Budaya. Yogyakarta: Pustaka Pelajar.

[8] Lutfi, M. (1976). Sejarah Riau. Pekanbaru. Pemerintah Daerah Propinsi Riau.

[9] Mahdini. (2003). Sastra Lisan Orang Banjar. Pekanbaru: Daulat Riau.

[10] Muthalib, A. (2008). Tuan Guru Sapat, Kiprah dan Peranannya dalam Pendidikan Islam di Indragiri Hilir Riau pada Abad ke-XX. Yokyakarta: Eja Publisher.

[11] Naim, M. (1984). Merantau, Pola Migrasi Suku Minangkabau. Yokyakarta: Gajah Mada University Press.

[12] Najib, M. (1996). Demokrasi dalam Perspektif Budaya Nusantara. Yogyakarta: LKPSM NU.

[13] Salim, H. (2001). Masyarakat Dayak Meratus, Agama resmi dan Emansipasi. Yogyakarta: Studi dan Pengembangan Borneo.

[14] Sihaloho, M. (2006). "Orientasi Pemilih Etnik Jawa dalam Pilkadasung tahun 2005 di Kota Medan". Jurnal Antropologi Sumatera. Vol.3. No.1. 2006. Hal. 414461.

[15] Spradley, J. P. (1972). The Ethnographic Interview. California: Wadsworth Publishing Company, Belmont.

[16] Tsing, A. L. (1998). Di Bawah Bayangbayang Ratu intan: Proses Marjinalisasi pada Masyarakat Terasing. Jakarta: Yayasan Obor Indonesia.
[17] Radam, N. H. (2001). Religi Urang Bukit. Yogyakarta: Yayasan Semesta. 